\title{
Fanconi Anemia Group I Protein
}

National Cancer Institute

\section{Source}

National Cancer Institute. Fanconi Anemia Group I Protein. NCI Thesaurus. Code C92482.

Fanconi anemia group I protein (1328 aa, $149 \mathrm{kDa}$ ) is encoded by the human FANCl gene. This protein plays a role in the repair of both DNA double-strand breaks by homologous recombination and of DNA cross-links. 